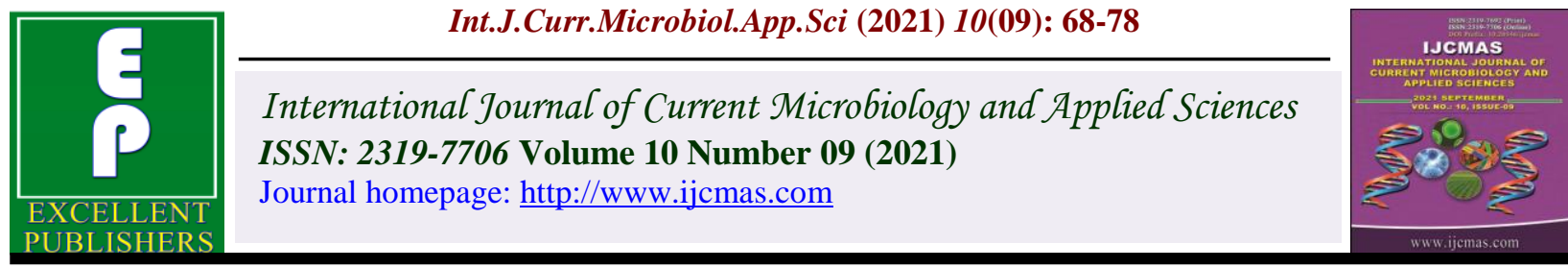

Original Research Article

https://doi.org/10.20546/ijcmas.2021.1009.008

\title{
Incidence of Citrus Tristeza Virus and its Vector Toxoptera citricida in Different Parts of Assam and Nagaland, India
}

\author{
Maongkar T. Changkiri ${ }^{1 *}$, Pulin Patgiri ${ }^{1}$, Palash Deb Nath ${ }^{2}$, \\ Rokozeno ${ }^{1}$ and Otto S. Awomi ${ }^{3}$
}

${ }^{1}$ Department of Entomology, ${ }^{2}$ Department of Plant Pathology, Assam Agricultural University, Jorhat - 785013, Assam, India

${ }^{3}$ Department of Entomology, School of Agricultural Science and Rural Development, Nagaland University, Medziphema Campus, Medziphema - 797106, Nagaland, India

*Corresponding author

\section{A B S T R A C T}

Keywords

Survey, CTV, DAS-

ELISA, Toxoptera

citricida, Disease

incidence, Assam,

Nagaland

Article Info

Accepted:

10 August 2021

Available Online:

10 September 2021
A field survey was conducted in 2018 to study the incidence of citrus tristeza virus (CTV) and its aphid vectors, in different citrus growing regions of the states of Assam and Nagaland, India. Leaf samples of Assam lemon (Citrus limon) and Khasi mandarin (Citrus reticulata) were collected from four districts of Assam (Jorhat, Tinsukia, Sivasagar and Golaghat) and two districts of Nagaland (Mokokchung and Wokha). Citrus leaf samples were collected from a total of 190 citrus plants and were used for detection of CTV infection through Double Antibody Sandwich-Enzyme linked Immuno-Sorbent Assay (DAS-ELISA). According to the results, 75 per cent CTV disease incidence was detected in surveyed areas of Assam and 24.55 per cent CTV disease incidence was detected in surveyed areas of Nagaland. District wise, the highest CTV disease incidence $(96.67 \%$ ) was detected in Tinsukia district of Assam and the lowest $(21.43 \%)$ was detected in Mokokchung district of Nagaland. Aphid samples were also collected during the survey and the presence of the vector Toxoptera citricida, in all the locations was determined.

\section{Introduction}

Citrus is an important fruit crop in India, ranking third after mango and banana. The total area under citrus in India is 1.06 million hectare producing 12.75 million tonnes (Anonymous, 2017a). Citrus is cultivated in almost every state of India, however due to the problem of citrus decline its productivity has been greatly hampered in recent years. In the 
state of Assam, the total area under orange is 17,358 hectare producing about 231642 tonnes and the total area under Assam lemon is 15,022 hectare producing 139404 tonnes (Anonymous, 2016). Similarly in the north eastern state of Nagaland, orange is cultivated in an area of 6,487 hectare producing about 54,650 tonnes and Lemon is cultivated in an area of 1,261 hectare producing about 9846 tonnes (Anonymous, 2017b).

Citrus tristeza virus (CTV), is one of the important causal agents of citrus decline disease worldwide and it has killed or caused decrease in production of more than 100 million citrus trees all over the world in the last 10 decades (Moreno et al., 2008).

Citrus tristeza virus, one of the prime causes of citrus die back has been reported from various states of India (Ahlawat et al., 1988, Capoor et al., 1963, Nariani et al., 1965, Vasudeva et al., 1958). In India CTV has been reported to causes leaf yellowing, growth cessation, chlorosis, plant stunting with poor fruit yield and quality, and ultimately tree decline (Chakroborty et al., 1992; Biswas, 2008; Sharma et al., 2011; Singh et al., 2013; Biswas et al., 2014). Citrus Tristeza Virus (CTV) is disseminated by grafting and some aphid species in a semi-persistent manner. CTV can only be transmitted by aphids and the brown citrus aphid T. citricida (Kirkaldy) has been found to be the most efficient vector (Bar-Joseph et al., 1979b). CTV is distributed in all the citrus-growing geographical zones in India: Northeast, South, Northwest and Central, with an estimated disease incidence ranging from 10 to $90 \%$ and infecting almost all the important citrus species, cultivars and hybrids in India (Chakraborty et al., 1992, Biswas 2008). In the Northeast, CTV is a major problem and $T$. citricida, the most efficient vector of CTV, is common (Ahlawat 1997, Biswas 2008). Considering the importance of Citrus tristeza virus (CTV) in the context of citrus production and productivity DAS-ELISA tool was used in this study to assess the prevalence of CTV in some citrus growing regions of Assam and Nagaland, India.

\section{Materials and Methods}

\section{Roving survey and collection of samples}

To assess the prevalence of Citrus Tristeza Virus, a survey was conducted in some citrus growing regions of Assam and Nagaland (India), in the year 2018. Samples were collected from four districts of Assam (Jorhat, Golaghat, Tinsukia and Sivasagar) and two districts of Nagaland (Mokokchung and Wokha). Studies on the incidence of CTV were carried out by collecting 10 young leave samples from all sides of 10 randomly selected trees from each orchard. The leave samples were collected in zip lock plastic bags, which were labelled and brought back to the laboratory, where it was stored in deep freezer for ELISA assay. In order to assess the aphid vector complex and the intensity of aphid infestation, ten (10) random plants from each orchard were selected. The intensity of aphid infestation was estimated with the help of the following scoring system. $0=$ no aphid, $1=1-4$ aphid infested twigs, $2=5-10$ aphid infested twigs, 3 => 10 aphid infested twigs. From each orchard aphid infested flushes were collected in labeled polythene bags and the aphids were later transferred into glass vials to be preserved in ethanol for identification. Data on elevation of the different locations were also collected during the field visits.

\section{Double-Antibody sandwich Enzyme-linked immune-sorbent assay (DAS-ELISA)}

To detect CTV in the leaves samples collected from different citrus growing areas, Double Antibody Sandwich ELISA was used following the recommended protocols. 


\section{Sensitization of plate}

Coating buffer (Appendix I) was used to dilute $\operatorname{IgG}(1000 x)$ into $1: 1000$ dilution $(20 \mu 1$ in 20 $\mathrm{ml})$. Each well of the microtiter plates were filled with $200 \mu \mathrm{l}$ of diluted IgG (Plate 1). The plates were wrapped with moist paper towel in order to prevent evaporation of the coating antibody solution and were placed inside plastic bags. The plates were incubated for 4 hours at $30^{\circ} \mathrm{C}$.

\section{Homogenization of samples}

Using mortar and pestle, leaf samples were homogenized in PBS-Tween (PBS-T). Approximately, $1 \mathrm{~g}$ of leaf sample was homogenized in $1 \mathrm{ml}$ of extraction buffer.

\section{Addition of samples}

Contents of wells were removed and washed 3 times with PBS-T for 1 minute each. Each well of the microtiter plates were filled with $200 \mu \mathrm{l}$ antigen (homogenized sample) and incubated at $4^{\circ} \mathrm{C}$ overnight (Plate 2).

\section{Addition of Conjugate}

Contents were removed and washed 3 times with PBST for 1 minute each. 200 $\mu 1$ diluted enzyme labeled antibody (conjugate) were added to each well (Plate 3). The plates were wrapped in moist paper towel, put into plastic bag and incubated at $30^{\circ} \mathrm{C}$ for 4 hours.

\section{Addition of substrate}

Contents were removed and washed, as above. $200 \mu 1$ of alkaline phosphatase substrate tablet dissolved in diethanolamine buffer ( $\mathrm{pH}$ 9.6), at a concentration of $1 \mathrm{mg} / \mathrm{ml}$ were added to each well and incubated at room temperature for 30 minutes to 1 hour (Plate 4). Per well $50 \mu 1$ of 3 $\mathrm{M} \mathrm{NaOH}$ were added, to stop the reaction and the microtiter plates were scanned at $405 \mathrm{~nm}$ in ELISA reader. Plants were considered infected with CTV, if the ELISA reading was observed to be four times above the average reading of the healthy samples (usually 20.1) (Azzam et al., 2001). The ELISA data were analyzed and per cent disease incidence was worked out.

Disease incidence was determined as:

$\%$ Incidence of CTV

$$
=\frac{\text { Number of ELISA positive plants }}{\text { Number of trees examined }} \mathrm{X} 100
$$

\section{Results and Discussion}

\section{Incidence of CTV}

During the present survey work, leaf samples were collected from 19 citrus growing regions of Assam and Nagaland, and were subjected to DAS-ELISA assay. The assay was performed successfully and the ELISA values (Virus titre values) were recorded. The data revealed that the highest mean ELISA values for all positive samples were maximum in Purani Motapong village (0.623) followed by Gelapukhuri village (0.423) from the district of Tinsukia, Assam. While, the lowest ELISA value was recorded in Yikhum village (0.090) from the district of Wokha, Nagaland. The results of the DAS-ELISA shows that virus titre in the infected plants was more in Purani Motapong village and Gelapukhuri village of Assam. The $\mathrm{OD}_{405}$ values ranged from 1.152 to -0.010 . The result also indicated that one location (Tsurang 1) from Nagaland was free of CTV infection (Table 1 and Fig.1). 
Table.1 ELISA values $\left(\mathrm{OD}_{405}\right)$ for extract of leaf tissues from different citrus growing regions of Assam and Nagaland

\begin{tabular}{|c|c|c|c|c|c|}
\hline State & District & villages & $\begin{array}{c}\text { Mean ELISA } \\
\text { for all positive } \\
\text { samples }\end{array}$ & $\begin{array}{c}\text { Maximun } \\
\text { ELISA } \\
\text { Value }\end{array}$ & $\begin{array}{c}\text { Minimum } \\
\text { ELISA } \\
\text { value }\end{array}$ \\
\hline Nagaland & Mokokchung & Mangmetong 1 & 0.159 & 0.214 & 0.026 \\
\hline & & Mangmetong 2 & 0.288 & 0.361 & 0.005 \\
\hline & & Yimchalu 1 & 0.094 & 0.094 & 0.000 \\
\hline & & Yimchalu 2 & 0.177 & 0.243 & 0.007 \\
\hline & & Tsurang 1 & 0.000 & 0.029 & -0.004 \\
\hline & & Tsurang 2 & 0.098 & 0.107 & -0.003 \\
\hline & & Yachang & 0.199 & 0.199 & -0.002 \\
\hline & & Elumyo & 0.150 & 0.175 & -0.010 \\
\hline & & Englan & 0.305 & 0.305 & 0.004 \\
\hline & & Yikhum & 0.090 & 0.106 & 0.007 \\
\hline \multirow{2}{*}{ Wssam } & & Humsto & 0.286 & 0.563 & 0.009 \\
\hline & \multirow{2}{*}{ Sivasagar } & Duwara Gaon & 0.372 & 0.963 & -0.002 \\
\hline & & Lahon Gaon & 0.385 & 0.724 & 0.025 \\
\hline & Tinsukia & Gelapukhuri & 0.423 & 1.152 & 0.144 \\
\hline & & Purani Motapong & 0.623 & 0.353 & 0.077 \\
\hline & & No. 2 & & & \\
\hline & & Tarajan Gaon & 0.269 & 0.581 & 0.025 \\
\hline & \multirow{2}{*}{ Golaghat } & Khumthai & 0.413 & 0.560 & 0.142 \\
\hline & & Sankala Gaon & 0.175 & 0.298 & 0.007 \\
\hline & Jorhat & AAU & 0.459 & 0.650 & 0.277 \\
\hline
\end{tabular}

Fig.1 ELISA values $\left(\mathrm{OD}_{405}\right)$ for extract of leaf tissues from different citrus growing regions of Assam and Nagaland

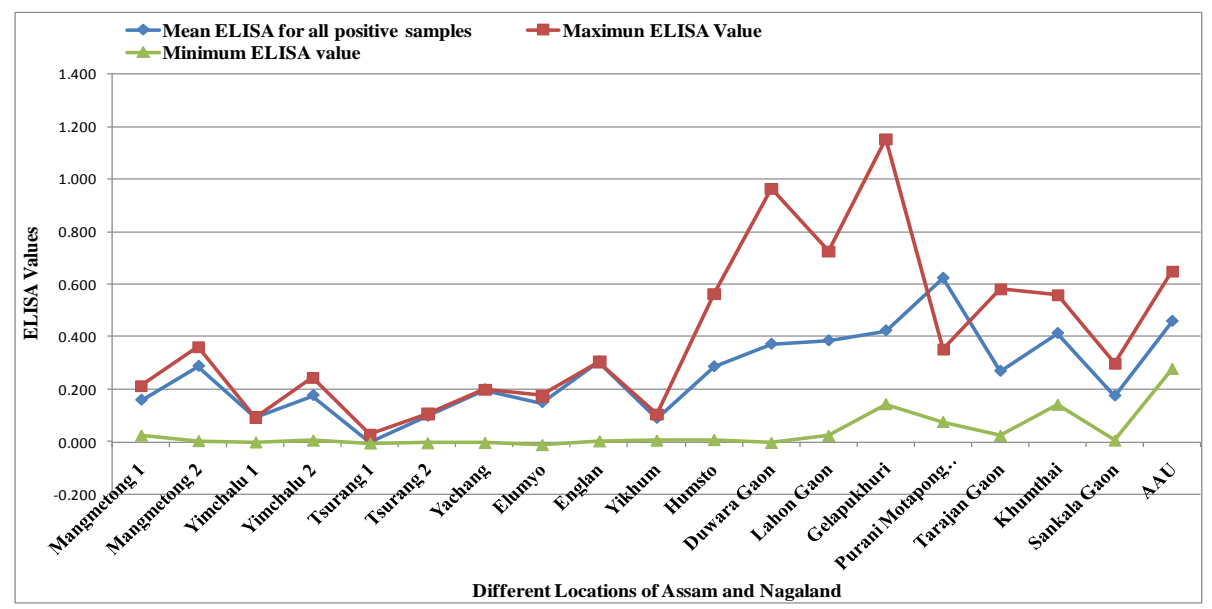


Table.2 CTV incidence in different villages of Assam and Nagaland

\begin{tabular}{|c|c|c|c|c|c|}
\hline State & $\begin{array}{c}\text { State wise Per } \\
\text { cent Infection } \\
(\%)\end{array}$ & District & villages & $\begin{array}{c}\text { Per cent } \\
\text { Infection }(\%)\end{array}$ & $\begin{array}{l}\text { District wise } \\
\text { Per cent } \\
\text { Infection }(\%)\end{array}$ \\
\hline \multirow[t]{11}{*}{ Nagaland } & 24.55 & Mokokchung & Mangmetong 1 & 50.00 & 21.43 \\
\hline & & & Mangmetong 2 & 20.00 & \\
\hline & & & Yimchalu 1 & 10.00 & \\
\hline & & & Yimchalu 2 & 30.00 & \\
\hline & & & Tsurang 1 & 0.00 & \\
\hline & & & Tsurang 2 & 30.00 & \\
\hline & & & Yachang & 10.00 & \\
\hline & & Wokha & Elumyo & 20.00 & 30.00 \\
\hline & & & Englan & 10.00 & \\
\hline & & & Yikhum & 20.00 & \\
\hline & & & Humsto & 70.00 & \\
\hline \multirow[t]{8}{*}{ Assam } & 75.00 & Sivasagar & Duwara Gaon & 70.00 & 55.00 \\
\hline & & & Lahon Gaon & 40.00 & \\
\hline & & Tinsukia & Gelapukhuri & 100.00 & 96.67 \\
\hline & & & $\begin{array}{c}\text { Purani Motapong } \\
\text { No. } 2\end{array}$ & 100.00 & \\
\hline & & & Tarajan Gaon & 90.00 & \\
\hline & & Golaghat & Khumthai & 60.00 & 55.00 \\
\hline & & & Sankala Gaon & 50.00 & \\
\hline & & Jorhat & AAU & 90.00 & 90.00 \\
\hline
\end{tabular}

Table.3 Elevation of the different study sites

\begin{tabular}{|c|c|c|c|}
\hline State & District & Village & Elevation (AMSL) \\
\hline Nagaland & Mokokchung & Mangmetong 1 & $1130 \mathrm{~m}$ \\
\hline & & Mangmetong 2 & $1120 \mathrm{~m}$ \\
\hline & & Yimchalu 1 & $835 \mathrm{~m}$ \\
\hline & & Yimchalu 2 & $822 \mathrm{~m}$ \\
\hline & & Tsurang 1 & $645 \mathrm{~m}$ \\
\hline & & Tsurang 2 & $628 \mathrm{~m}$ \\
\hline & & Yachang & $115 \mathrm{~m}$ \\
\hline & Wokha & Elumyo & $928 \mathrm{~m}$ \\
\hline & & Englan & $785 \mathrm{~m}$ \\
\hline & & Yikhum & $816 \mathrm{~m}$ \\
\hline & & Humsto & $1065 \mathrm{~m}$ \\
\hline & Sivasagar & Duwara Gaon & $99 \mathrm{~m}$ \\
\hline & & Lahon Gaon & $98 \mathrm{~m}$ \\
\hline & Tinsukia & Gelapukhuri & $111 \mathrm{~m}$ \\
\hline & & Purani Motapong No. 2 & $97 \mathrm{~m}$ \\
\hline & & Tarajan Gaon & $122 \mathrm{~m}$ \\
\hline & Golaghat & Khumthai & $81 \mathrm{~m}$ \\
\hline & & Sankala Gaon & $79 \mathrm{~m}$ \\
\hline & Jorhat & AAU & $100 \mathrm{~m}$ \\
\hline
\end{tabular}

*AMSL- Above mean sea level, m- Meter 
Table.4 Intensity of aphid infestation at different study sites

\begin{tabular}{|c|c|c|c|}
\hline State & District & Village & Level of aphid infestation \\
\hline Nagaland & Mokokchung & Mangmetong 1 & 2 \\
\hline & & Mangmetong 2 & 1 \\
\hline & & Yimchalu 1 & 1 \\
\hline & & Yimchalu 2 & 1 \\
\hline & & Tsurang 1 & 1 \\
\hline & & Tsurang 2 & 1 \\
\hline & Wokha & Yachang & 2 \\
\hline & & Elumyo & 1 \\
\hline & & Englan & 2 \\
\hline \multirow{2}{*}{ Assam } & & Yikhum & 2 \\
\hline & Sivasagar & Humsto & 2 \\
\hline & & Duwara Gaon & 2 \\
\hline & Tinsukia & Lahon Gaon & 3 \\
\hline & & Gelapukhuri & 3 \\
\hline & & Purani Motapong No. 2 & 2 \\
\hline & Golaghat & Tarajan Gaon & 3 \\
\hline & & Khumthai & 3 \\
\hline
\end{tabular}

$* 0=$ no aphid, $1=1-4$ aphid infested twigs, $2=5-10$ aphid infested twigs, $3=>10$ aphid infested twigs

Fig.2 CTV incidence at different villages of Assam and Nagaland

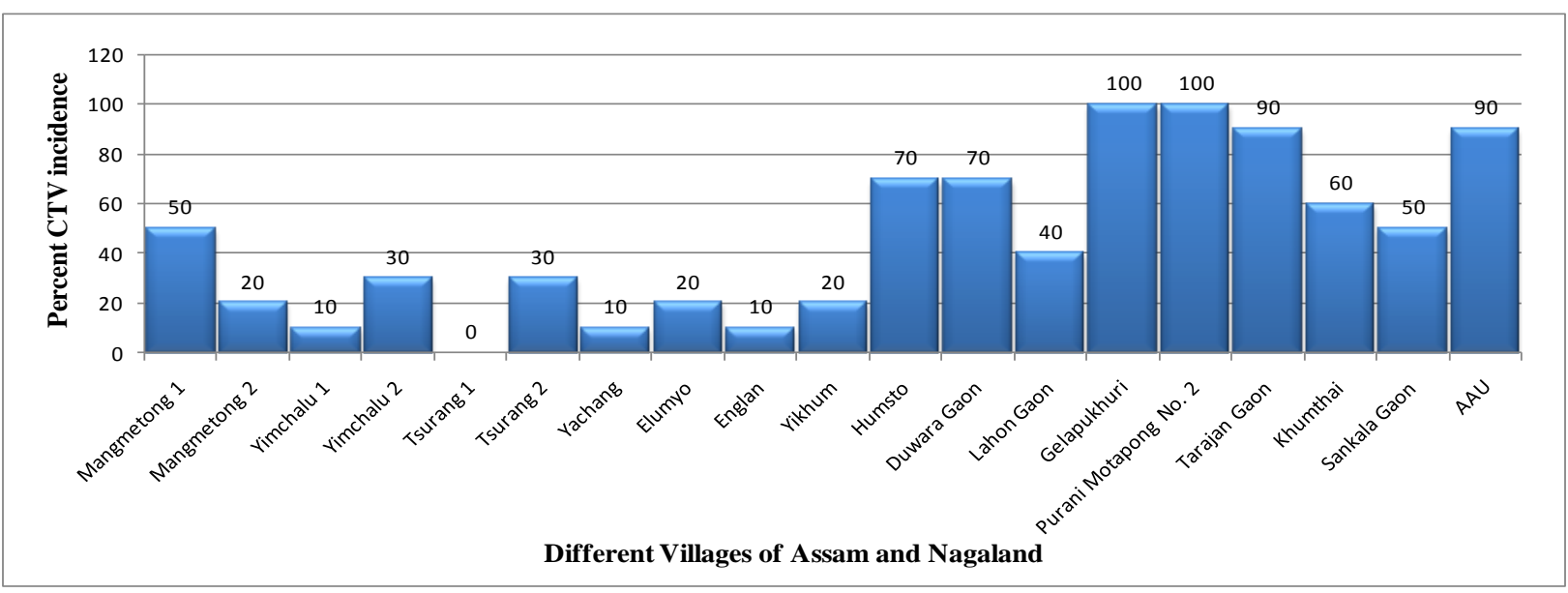


Plate 1: Coating of Primary Antibody

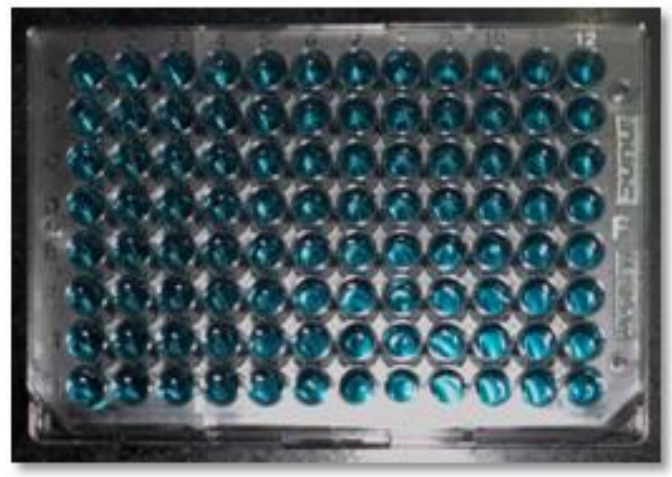

Plate 3: Coating of Conjugate

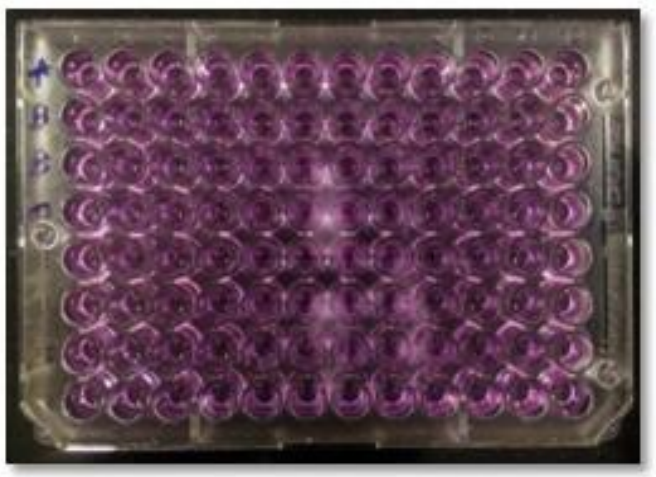

Plate 2: Coating of Grinded Samples

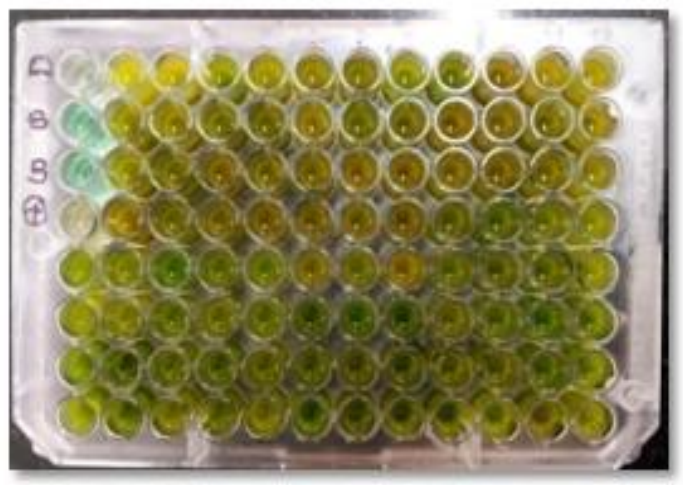

Plate 4: Addition of Substrate

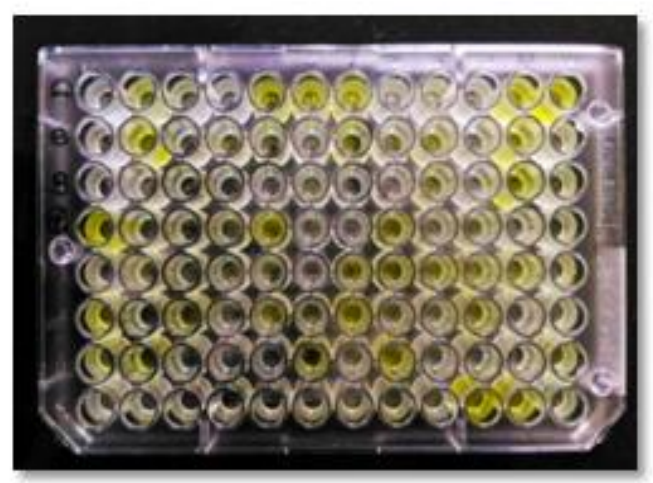

Plate.5 T. citricida on Assam Lemon

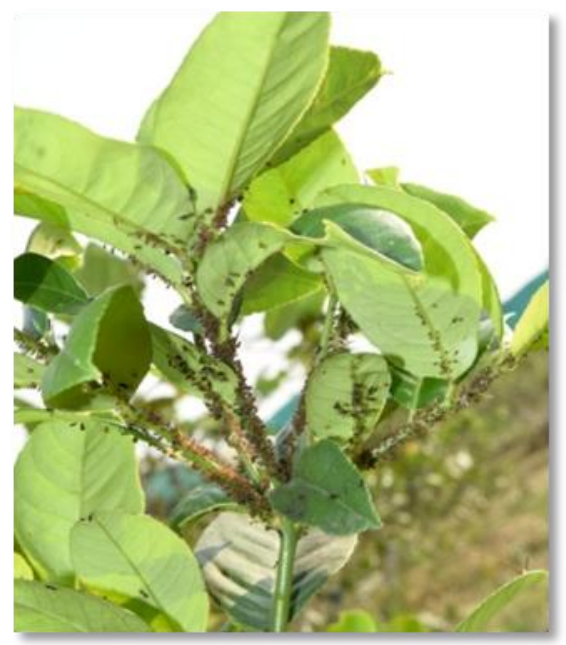


Plate.6 Adults (apterae) and nymphs of T. citricida

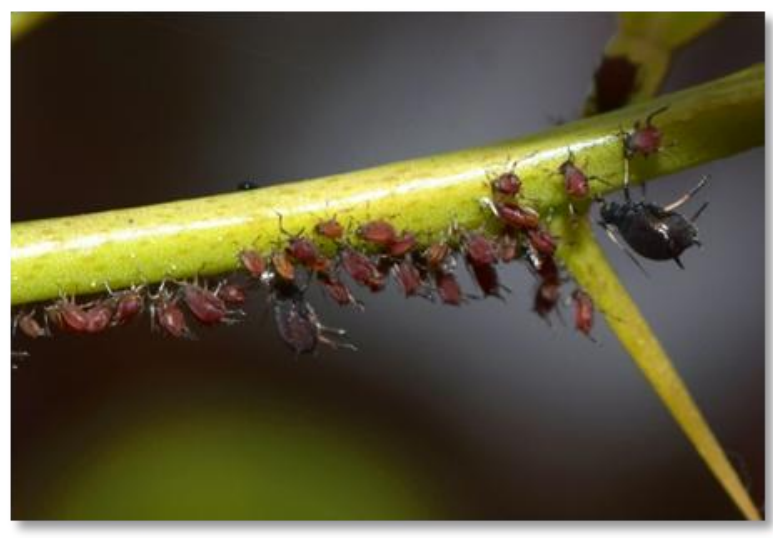

Plate.7 Adults (alatae) of T. citricida

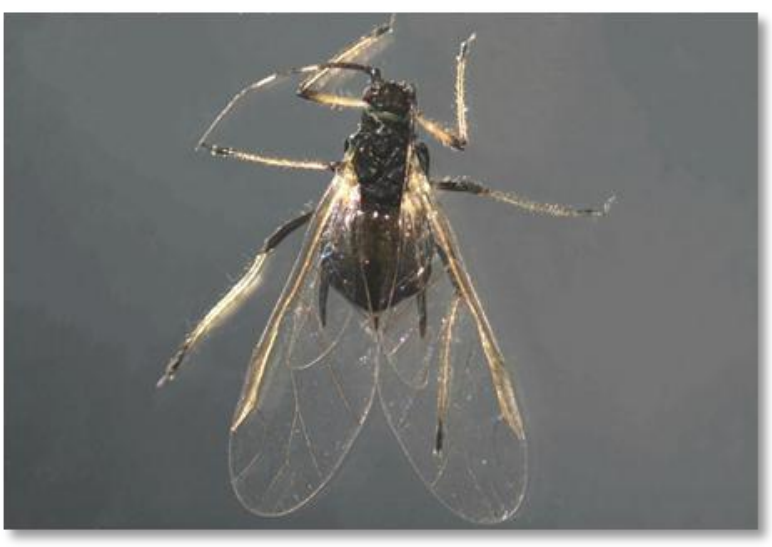

Fig.3 Relationship between Elevation and incidence of CTV

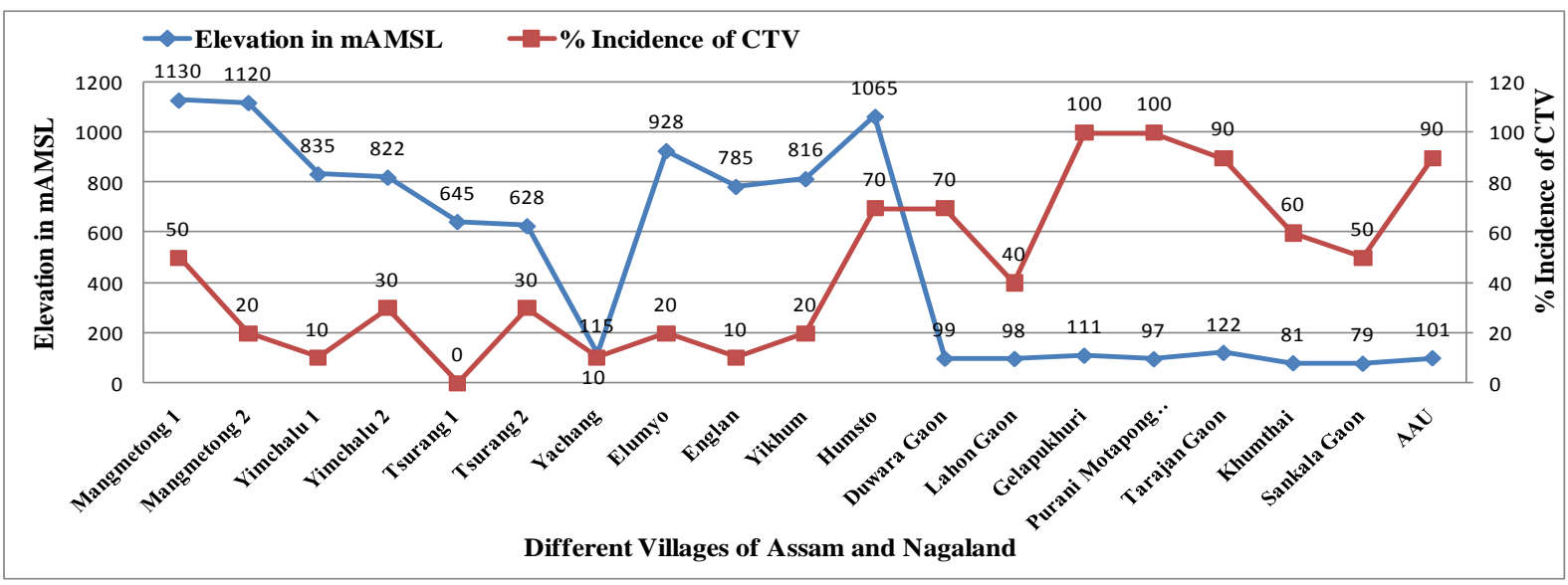

Fig.4 Relationship between Level of Aphid Infestation and incidence of CTV

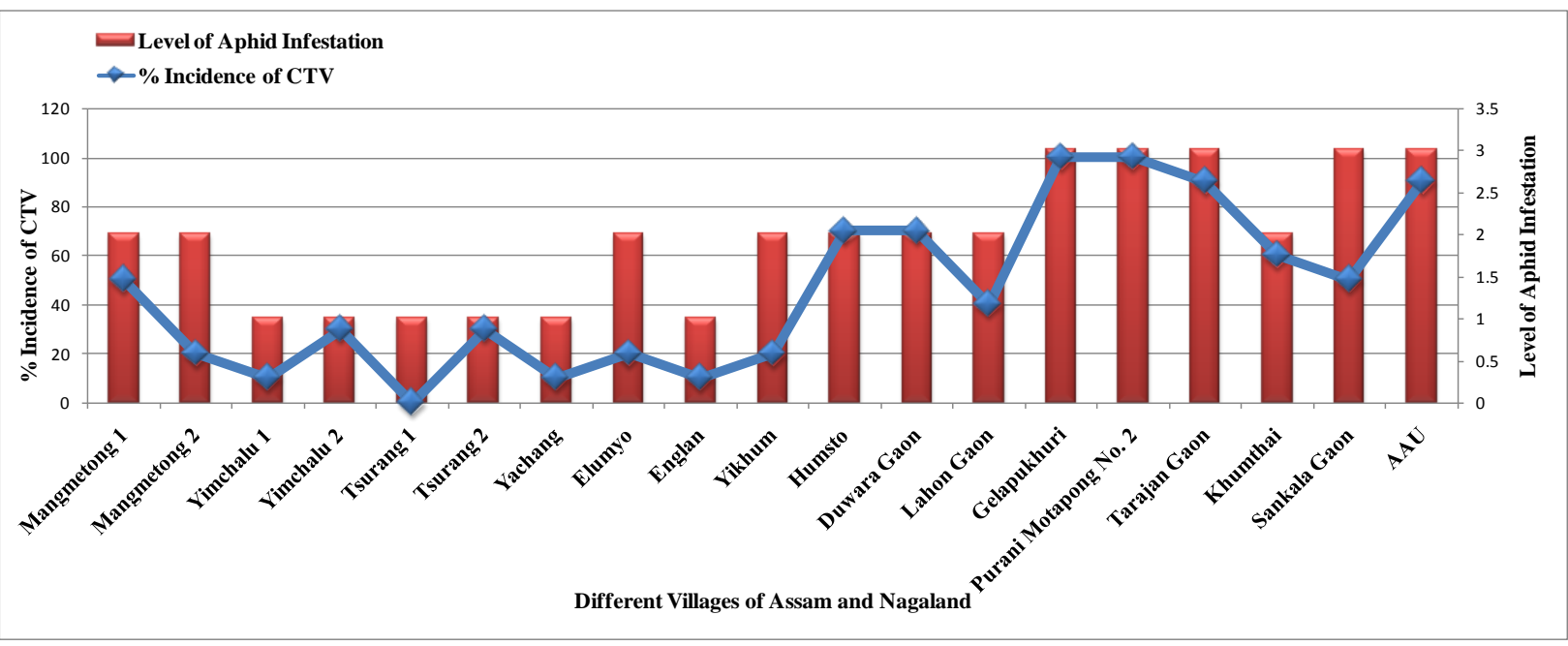


According to the DAS-ELISA results, 60 out of 80 citrus plants were found to be infected with CTV indicating 75 per cent CTV disease incidence in surveyed areas of Assam and 27 out of 110 citrus plants collected from Nagaland were found to be infected with CTV indicating 24.55 per cent CTV disease incidence in surveyed areas of Nagaland. The results revealed the presence of CTV in all the surveyed districts of Assam and Nagaland and the highest CTV disease incidence (96.67 \%) was detected in Tinsukia district of Assam and the lowest $(21.43 \%)$ was detected in Mokokchung district of Nagaland (Table 2 and Fig.2). Singh et al., (2017) also reported CTV incidence of 66 per cent in Arunachal Pradesh followed by 62 per cent in Assam, 60 per cent in Meghalaya and Nagaland, 54 per cent Sikkim and 42.33 per cent in Tripura. Borah et al., (2012) reported CTV incidence of 63.50 per cent in citrus growing regions of Assam. Kishore et al., (2010) and Iftikhar et al., (2009) also reported the incidence of CTV using ELISA technique.

During the study the elevation of the different sites visited were recorded to understand the relation between the incidences of CTV and elevation of the sites. The elevation of the different locations ranged from 79 - 1130m AMSL (Table 3 and Fig. 3). The data on elevation and percent incidence of CTV was subjected to correlation studies and the results indicated a significant and negative correlation $(\mathrm{r}=-0.536)$ between CTV disease incidence and elevation of the different sites. The finding suggests that the incidence of CTV decreases as the elevation increases. However, such results have not been reported in the past and hence, warrant further investigation.

\section{Incidence of CTV aphid vector T. citricida}

The aphid samples collected during the study were preserved in $70 \%$ alcohol and were identified from the National Bureau of Agricultural Insect Resources (NBAIR), Bengaluru. During the present investigation, a single aphid species T. citricida (Plate 5, 6 and 7) belonging to the family Aphididae and commonly known as brown citrus aphid (BCA) was identified from all the locations. The presence of $T$. citricida in citrus plants of the north eastern regions of India has also been reported by Kishore et al., (2010), Ghosh et al., (2015) and Borah et al., (2012).

Level of aphid infestation was also recorded for all the location and correlated with incidence of CTV (Table 4 and Fig. 4). The result indicated a significant and positive correlation $(\mathrm{r}=0.832)$ between CTV incidence and level of aphid infestation. The finding suggests that the incidence of CTV increases as the level of aphid infestation increases. From the present investigation it can be concluded that the CTV is widely spread with high incidence percentage in all the surveyed areas of Assam and Nagaland. DAS-ELISA was found to be very accurate and efficient in detection of CTV, which could be important tool in certification of CTV-free planting materials. The above findings draw the conclusion that $T$. citricida is an important sap sucking pest of citrus and an important vector of CTV, prevalent in both the states of Assam and Nagaland.

\section{Acknowledgements}

The authors are thankful to the Department of Entomology and Plant Pathology, Assam Agricultural University, for providing the necessary laboratory facility.

\section{References}

Ahlawat, R. S. and Raychaudhuri, S. P. (1988). Status of citrus tristeza and dieback diseases in India and their 
detection. Proceedings of the Sixth International Citrus Congress, Tel Aviv, pp. 871-879.

Ahlawat, Y. S. (1997). Viruses, greening bacterium and viroids associated with citrus (Citrus species) decline in India. Indian J. Agric. Sci. 67: 51-57.

Anonymous. (2016). Statistical Hand Book Assam. Directorate of Economics and Statistics, Government of Assam, Guwahati-28. Pp. 131.

Anonymous. (2017a). Horticultural Statistics at a Glance. Horticulture Statistics Division Department of Agriculture, Cooperation \& Farmers Welfare Ministry of Agriculture \& Farmers Welfare Government of India. Pp. 145158.

Anonymous. (2017b). Statistical Hand Book of Nagaland. Directorate of Economics and Statistics, Government of Nagaland, Kohima. Pp.37.

Azzam, O.; Imbe, T.; Ikeda, R.; Nath, P.D. and Coloquio, E. (2001). Inheritance of resistance to Rice tungro spherical virus in anear isogenic line derived from Utri Merah and in rice cultivar TKM6. Euphytica. 122 (1): 91-97.

Bar-Joseph, M.; Garnsey, S. N. and Gorsalves, D. (1979b). The closteroviruses: A distinct group of elongated plant viruses. Adv. Virus Res. 25: 99-168.

Biswas, K. K. (2008). Molecular diagnosis of Citrus tristeza virus in mandarin (Citrus reticulata) orchards of hills of West Bengal. Indian J. Virol. 19: 2631.

Biswas, K. K.; Tarafdar, A.; Sharma, S. K.; Singh, J. K.; Dwivedi, S.; Biswas, K. and Jayakumar, B. K. (2014). Current status of Citrus tristeza virus incidence and its spatial distribution in citrus growing geographical zones of India. Indian J. Agric. Sci. 84: 8-13.

Borah, M.; Nath, P. D and Saikia, A. K. (2012). Serological detection of Citrus tristeza virus affecting citrus tree species in Assam. Indian Phytopathol. 65(3): 289-293.

Capoor, S. P. (1963). Decline of citrus trees in India. Bull. Nat. Inst. Sci. India. 24: 48-64.

Chakraborty, N. K.; Ahlawat, Y. S.; Varma, A.; Chandra, K. J.; Ramapandu, S.; Kapur, S. P. (1992). Proceeding of the 12th Conference of the International Organization of Citrus Virologists, India (IOCV, Riverside, 1992). pp. 108

Ghosh, A.; Das, A.; Lepcha, R.; Majumdar, K and Baranwal, V. K. (2015). Identification and distribution of aphid vectores spreading Citrus tristeza virus in Darjeeling hills and Dooars of India. Journal of Asia Pacific Entomology. 18:601-605

Iftikhar, Y.; Khan, M. A.; Rashid, A.; Mughal, S. M.; Iqbal, Z.; Batool, A.; Abbas, M.; Khan, M. M.; Muhammad, S. and Jaskani, M. J. (2009). Occurrence and distribution of citrus tristeza closterovirus in Punjab and NEFP, Pakistan. Pak. J. Bot. 41: 373-380.

Kishore, K.; Rahman, H.; Kalita, H.; Pandey, B. and Monika, N. (2010). Prevalence of Citrus tristeza virus in Mandarin of Sikkim Himalayan Region. Indian J. Virol. 21(2): 140-143.

Moreno, P., Ambros, S., Albiach-Marti, M. R., Guerri, J and Pena, L. 2008. Citrus tristeza virus: a pathogen that changed the course of the citrus industry. Mol Plant Pathol. 9: 251-268.

Nariani T K, Sahambi H S, Chona B L. 1965. Occurrence of tristeza virus in citrus in northern India. Indian Phytopath. 18: 220.

Sharma, S. K., Tarafdar, A., Khatun, D., Kumari, S and Biswas, K. K. 2011. Intra-farm diversity and evidence of genetic recombination of Citrus tristeza virus isolates in Delhi region of India. JPBB. 21(1): 38-43. 
Singh, A. K.; Meetei, N. T.; Singh, B. K. and Mandal, N. (2017). High incidence of citrus tristeza virus in mandarin (Citrus reticulata) in North-East states of India. Virus Dis. 28(4):401-407.

Singh, J. K., Tarafdar, A., Sharma, S. K. and Biswas, K. K. 2013. Evidence of recombinant Citrus tristeza virus isolate occurring in Acid Lime cv. Pant Lemon orchard in Uttarakhand Terai region of Northern Himalaya in India. Virus Disease. 24: 35-41.

Vasudeva R S, Capoor S P. (1958). Citrus decline in Bombay state. FAO Plant Prot. Bull. 6: 91.

\section{How to cite this article:}

Maongkar T. Changkiri, Pulin Patgiri, Palash Deb Nath, Rokozeno and Otto S. Awomi. 2021. Incidence of Citrus Tristeza Virus and its Vector Toxoptera citricida in Different Parts of Assam and Nagaland, India. Int.J.Curr.Microbiol.App.Sci. 10(09): 68-78.

doi: https://doi.org/10.20546/ijcmas.2021.1009.008 